2014

\title{
Retroactivity and Prospectivity of Judgments in American Law
}

\author{
Richard Kay \\ University of Connecticut School of Law
}

Follow this and additional works at: https://opencommons.uconn.edu/law_papers

Part of the Constitutional Law Commons, Jurisprudence Commons, and the Rule of Law Commons

\section{Recommended Citation}

Kay, Richard, "Retroactivity and Prospectivity of Judgments in American Law" (2014). Faculty Articles and Papers. 287.

https://opencommons.uconn.edu/law_papers/287 


\section{HEINONLINE}

Citation: 62 Am. J. Comp. L. Supp. 372014

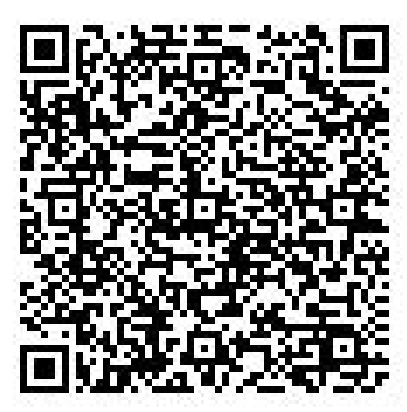

Content downloaded/printed from HeinOnline (http://heinonline.org) Mon Aug 15 16:56:53 2016

-- Your use of this HeinOnline PDF indicates your acceptance of HeinOnline's Terms and Conditions of the license agreement available at http://heinonline.org/HOL/License

-- The search text of this PDF is generated from uncorrected OCR text.

-- To obtain permission to use this article beyond the scope of your HeinOnline license, please use:

https://www.copyright.com/ccc/basicSearch.do? \&operation $=$ go\&search Type $=0$ \&lastSearch $=$ simple\&all $=0 n \&$ titleOrStdNo=0002-919X 


\title{
RICHARD S. KAY*
}

\section{Retroactivity and Prospectivity of Judgments in American Law ${ }^{\dagger}$}

\author{
TopIC I. B
}

In every American jurisdiction, new rules of law announced by a court are presumed to have retrospective effect-that is, they are presumed to apply to events occurring before the date of judgment. There are, however, exceptions in certain cases where a court believes that such application of the new rule will upset serious and reasonable reliance on the prior state of the law. This report summarizes these exceptional cases. It shows that the proper occasions for issuing exclusively or partially prospective judgments have varied over time and that there are still substantial differences in approach according to the particular jurisdiction and the kind of law under consideration. The report concludes with a brief survey of some of the still unresolved jurisprudential and constitutional problems raised by recognition of the power of courts to issue non-retroactive judgments.

\section{INTRODUCTION}

Appellate decisions generally consist of two elements-the resolution of a dispute and a statement of law explaining that resolution. ${ }^{1}$ The former can only be retroactive-a judge cannot resolve a case before it arises. Prospectivity and retroactivity only present issues with respect to the general explanatory statements of law. Because the more general statements are a court's best explanation of the legal rules governing certain facts, they ought to apply to other cases based on the same kinds of facts arising both before and after the judgment.

To the extent that a court creates or changes a rule of law in a given case and then applies it to other cases based on past conduct, it

* Wallace Stevens Professor of Law, University of Connecticut School of Law. This is a substantially abridged version of the United States report submitted for the topic, "Judicial Rulings with Prospective Effect" at the XIXth International Congress of Comparative Law, 2014. Scott Garosshen provided essential research and editorial assistance.

$\dagger$ DOI: http://dx.doi.org/10.5131/AJCL.2013.0017

1. Julius Stone, Precedent and Law 188 (1985). 
regulates that conduct by a retroactive rule. This raises immediate alarms. In American law, as in most law, retroactive rules are disfavored. The United States Supreme Court expressed the prevailing attitude:

Elementary considerations of fairness dictate that individuals should have an opportunity to know what the law is and to conform their conduct accordingly; settled expectations should not be lightly disrupted. For that reason, the principle that the legal effect of conduct should ordinarily be assessed under the law that existed when the conduct took place has timeless and universal appeal. ${ }^{2}$

Several provisions of the Unites States Constitution are motivated, at least in part, by concerns about the evils of retroactive law ${ }^{3}$ and American courts interpreting legislation indulge a strong presumption against retroactivity. ${ }^{4}$

The attitude, however, is quite the opposite when it comes to the judgments of courts. The strong presumption is that statements of law in judgments that announce new rules or overturn old ones apply to conduct predating that judgment. This seeming inconsistency derives from the "declaratory" theory of adjudication-legislatures make new law but courts only find and declare pre-existing law. ${ }^{5}$ Blackstone, whose influence on American law was great, understood judgments as merely "the principal and most authoritative evidence" of a law with a prior and independent existence. ${ }^{6}$ Courts engage in interpretive not creative acts. ${ }^{7}$ Joseph Story, a preeminent early American legal authority, embraced this idea with enthusiasm. Legal rules, he claimed, were "antecedent" to judicial decisions and the latter were valuable only for "their supposed conformity to those rules." 8 From this understanding it follows that rules announced by the legis-

2. Landgraf v. USI Film Prods., 511 U.S. 244, 265-66 (1994) (quoting Kaiser Aluminum \& Chem. Corp. v. Bonjorno, 494 U.S. 827, 855 (Scalia, J., concurring) (citations omitted)).

3. U.S. Const. art I, $\S 9$, cl. 3 (federal); id. art. I, $\$ 10$, cl. 1 (states) (no ex post facto laws); art I, $\S 9$, cl. 3 (federal); id. art. I, $\S 10$, cl. 1 (states) (no bills of attainder); art I, $\S 10$, cl. 1(states)(no impairment of the obligation of contracts); amend. V (federal) (no taking of property without just compensation); amends. V (federal), XIV (states) (no deprivation of life, liberty or property without due process of law).

4. Landgraf, 511 U.S. at 265.

5. See, e.g., Prentis v. Atl. Coast Line Co., 211 U.S. 210, 226 (1908).

6. 1 William Blackstone, Commentaries *69.

7. George P. Fletcher, Paradoxes in Legal Thought, 85 Colum. L. Rev. 1263, 1273 (1985) (Courts do not "bring new laws into being," but provide "readings or renditions of the meaning implicit in some independently existing, external object.").

8. Joseph Story, Value and Importance of Legal Studies, in The Miscellaneous Writings of JosePh Story 503, 508 (William W. Story ed., Da Capo Press 1972) (1852). 
lature have only prospective effect while those announced by judges have retroactive effect as well. ${ }^{9}$

Modern jurisprudence, of course, has largely debunked this view and has recognized an inevitable law-making power in courts. ${ }^{10} \mathrm{It}$ might follow that the retroactivity of rules arising from adjudication is as worrisome as that associated with legislation. That is, we should expect cases in which people have acted in substantial and reasonable reliance on the law that preceded introduction of the "new rule" by a court. In such cases, it might make sense to apply new judicial rules, like new legislative rules, only to the future. So, when, in 1848, the Ohio Supreme Court held legislative divorces unconstitutional, it recognized that "second marriages [had] been contracted" based on such divorces and retroactive application of its decision would "bastardize" the children born of those marriages. It was enough that the court had declared the correct state of the law. It felt "confident that no department of state has any disposition to violate it, and that the evil will cease"11

In the early twentieth century, as the force of the declaratory theory began to wane, this idea of limiting judgments' effect to future transactions was increasingly proposed as a reasonable approach when courts created new legal rules and especially when they overruled established precedent. In 1921, Chief Judge (as he then was) Benjamin Cardozo noted that in some cases:

when the hardship [of the retroactive effect of judge-made law] is felt to be too great or to be unnecessary, retrospective operation is withheld. . . . It may be hard to square such a ruling with abstract dogmas and definitions. When so much else that a court does, is done with retroactive force, why draw the line here? The answer is, I think, that the line is drawn here, because the injustice and oppression of a refusal to draw it would be so great as to be intolerable. ${ }^{12}$

9. Similarly, the constitutional provisions that prohibit retroactive laws generally have been held inapplicable to judicial acts. See, e.g., Frank v. Mangum, 237 U.S. 309, 344 (1915) (ex post facto laws); Tidal Oil Co. v. Flanagan, 263 U.S. 444 (1924) (impairment of contracts). But see Gibson v. Am. Cyanamid Co., 719 F. Supp. 2d 1031, 1041-45 (E.D. Wis. 2010) (retroactive application of new tort liability violates due process clause of fourteenth amendment). The United States Supreme Court has sometimes attempted to restrain judicial innovation resulting in unexpected imposition of criminal liability. See infra Part III.A.

10. See, e.g., Richard H. Fallon, Jr. \& Daniel J. Meltzer, New Law, Non-Retroactivity and Constitutional Remedies, 104 HaRv. L. REv. 1731, 1759 (1991) "It would only be a slight exaggeration to say that there are no more Blackstonians.")

11. Bingham v. Miller, 17 Ohio 445, 448-49 (1848).

12. Benjamin Cardozo, The Nature of the Judicial Process, $146-47$ (1921). By this time the practice had already been noted and defended in legal commentary. Beryl Harold Levy, Realist Jurisprudence and Prospective Overruling, 109 U. PA. L. REV 1, 10 (1960). 
The practice had become prominent enough by 1931 that an article in the American Bar Association Journal proposed that legislatures explicitly authorize courts to declare that new judge-made rules would operate only prospectively. ${ }^{13}$

In 1932, the constitutionality of such "prospective overruling" was challenged in the United States Supreme Court. ${ }^{14}$ The Montana Supreme Court had previously held that when the Montana Railroad Commission reversed its prior determination of freight charges' reasonableness, shippers could recover the excess amounts paid under the earlier dispensation. The Montana court overruled that interpretation but applied the old rule to the parties before it, allowing the shipper to recover the unreasonable charges. ${ }^{15}$ The railroad argued that this deprived it of property without due process of law because it had been forced to refund the payments based on an interpretation of the statute now acknowledged to be wrong. ${ }^{16}$ In Great Northern Railway. Co. v. Sunburst Oil \& Refining Co., the Supreme Court rejected this argument in a unanimous decision written by now Justice Cardozo. A state court was entitled to "make a choice for itself between the principle of forward operation and that of relation backward. It may say that decisions of its highest court, though later overruled, are law none the less for intermediate transactions." 17 The "declaratory" understanding of adjudication was merely one of several permissible approaches:

The choice for any state may be determined by the juristic philosophy of the judges of her courts, their conceptions of law, its origin and nature. ... [W]e may say of the earlier decision that it has not been overruled at all. It has been translated into a judgment of affirmance and recognized as law anew. Accompanying the recognition is a prophecy, which may or may not be realized in conduct, that transactions arising in the future will be governed by a different rule. ... . [W] e are not at liberty, for anything contained in the constitution of the United States, to thrust upon those courts a different conception either of the binding force of precedent or of the meaning of the judicial process. ${ }^{18}$

This decision put to rest any constitutional concerns with state courts' prospective judgments.

13. Albert Kocourek, Retrospective Decisions and Stare Decisis and $\alpha$ Proposal, 17 A.B.A.J. 180 (1931).

14. Great N. Ry. Co. v. Sunburst Oil \& Refining Co., 287 U.S. 358 (1932).

15. Id. at $360-61$.

16. Id. at 359 .

17. Id. at 364 (emphasis added) (citations omitted).

18. Id. at 365-66 (citations omitted). 
The balance of this report will examine how courts have responded to this possibility and will attempt to summarize the state of the law. This attempt is complicated by the federal character of the jurisdiction. The relevant law is often different from state to state. My summary account of state law, therefore, must be more indicative than definitive. In addition, I will describe the same issues in federal law-the law of the United States. Although it will be apparent that the division is in some ways artificial, I will also divide the treatment between judgments of civil law and criminal law.

\section{Prospective Judgments in Civil Law}

\section{A. State Courts}

Statements of law contained in a judgment are presumed to apply to events predating that judgment. The negative impact of this retroactive application of judicially created rules must be substantial before a court will consider limiting the rules to future cases. When deciding whether to depart from the default of full retroactivity, the foremost consideration is the nature and degree of likely reliance on the prior state of the law. This consideration "can hardly be overemphasized." 19 Courts view some fields of law-such as contract and property-as especially likely to induce such reliance. Apart from the injustice of erasing or devaluing rights deemed to have already "vested" in their holders, ${ }^{20}$ these are fields where individuals may have actually paid attention to existing rules of law, perhaps even consulted legal advisers, before engaging in a given transaction. ${ }^{21}$

By contrast, new rules of tort law seldom upset significant reliance interests. "Ordinarily," for example, "persons who drive carelessly do not do so in conscious reliance upon some rule of law." 22 The scope of tort liability, however, may affect some decisions on whether and how much insurance a party obtains, as well as the decision to investigate an incident for which it might be held liable. Therefore, courts often made their decisions eliminating tort immu-

19. Beavers v. Johnson Controls World Servs., Inc., 881 P. 2d 1376, 1384 (N.M. 1994)

20. See Roger J. Traynor, Quo Vadis, Prospective Overruling: A Question of Judicial Responsibility 28 HAstings L.J. 533, 544 (1977).

21. See id.; accord. Thomas S. Currier, Time and Change in Judge-Made Law: Prospective Overruling, 51 VA. L. Rev. 201, 242 (1965); Melvin A. EisenberG, The Nature of the Common LAw 122 (1998).

22. Thomas E. Fairchild, Limitation of New Judge-Made Law to Prospective Effect Only: "Prospective Overruling" or "Sunbursting," 51 MARQ. L. REv. 254, 261 (1967-68). The same may be true of "strict liability" torts and certain intentional torts to the person such as battery, assault or infliction of mental distress. On the other hand, intentional torts to property, such as trespass or conversion, may sometimes be the result of deliberate decision. Likewise, some instances of defamation or misrepresentation might be undertaken only after consideration of the relevant law. 
nity for municipalities and charitable institutions prospective-only. ${ }^{23}$ Notably, in calculating the reliance that justifies making judicial decisions non-retroactive, courts almost always consider categories of cases; not the presence or absence of reliance by the particular parties before the court. ${ }^{24}$

Whenever prospective operation is suggested there are necessarily competing considerations. Retroactive application might undermine reasonable actions taken in reliance on the former law. But the new judgment, by definition, supposes the altered rule to be superior to the old one. Prospective-only operation, therefore, entails a decision to apply an inferior rule to prior transactions. In accommodating the relevant factors, many state courts have settled on some variation of a test formulated by the United States Supreme Court in its 1971 decision in Chevron Oil Co. v. Huson. ${ }^{25}$ The test considers three factors:

1) whether the decision to be applied non-retroactively establishes a new principle of law, either by overruling clear past precedent or by deciding an issue of first impression;

2) if, in light the new rule's purpose and effect, retrospective operation would further or retard its operation; and

3) the extent of the inequity imposed by retroactive application, namely the injustice or hardship that would be caused by retroactive application. ${ }^{26}$

A court examines these factors, it must be stressed, against the background presumption that retroactivity is "overwhelmingly the norm." 27 Thus a litigant seeking prospective-only application must firmly convince a court that each factor favors such a decision.

23. See, e.g., Parker v. Port Huron Hosp., 105 N.W.2d 1, 14-15 (Mich. 1960); Thomas J. Dufour, Note, The Proper Application of Judicial Decisions Overruling Established Tort Doctrines, 65 B.U. L. REv. 315, 331 (1985).

24. Walter V. Schaefer, The Control of "Sunbursts": Techniques of Prospective Overruling, 42 N.Y.U. L. REv. 631, 642-43 (1967). But see Garfias-Rodriguez v. Holder, 702 F.3d 504, 519-20 (9th Cir. 2012) (actual reliance on the old law by the party before the agency is relevant to the possible prospective application of a rule created in administrative adjudication). Some doubt has been expressed about how often primary conduct is influenced by consideration of the current law. Note, Prospective Overruling and Retroactive Application in the Federal Courts, 71 YALE L.J. 907, 946 (1962) ("Thus in many cases, the parties, because of their not uncommon ignorance of the legal principle that controls their actions, will not be able to make a bona fide claim of surprise.").

25. 404 U.S. 97 (1971). See, e.g., Beavers v. Johnson Controls World Servs., Inc., 881 P.2d 1376 , 1381-85 (N.M. 1994); DiCenzo v. A-Best Prods. Co., 897 N.E.2d 132, 135-41 (Ohio 2008); Caperton v. A.T. Massey Coal Co., 690 S.E.2d 322, 351-52 (W. Va. 2009). The Chevron Oil case is discussed further at infra text accompanying notes 5462.

26. Paraphrased from Chevron Oil, 404 U.S. at 106-07.

27. James B. Beam Distilling Co. v. Georgia, 501 U.S. 529, 535 (1991) (opinion of Souter J.). 
Once we have established that a court may limit the retroactive application of its judgment, other questions arise. Such a decision might mean that the new rule is to apply only to primary conduct occurring after the date the decision is announced and to no conduct occurring before that date. While that is sometimes the case, there are other possibilities. A court might make a new norm partly retroactive, applying it to some but not all past events. For example, when the Connecticut Supreme Court expanded an enterprise's "slip and fall" tort liability to include injuries caused by a foreseeably unsafe "mode of operation," it applied its holding to "all future cases and, as a general rule, to all previously filed cases in which the trial has not yet commenced ...."28 The court apparently concluded that the costs of adjusting to the new rule would not be excessive if litigation had not yet reached the trial stage.

The simple approach of starting the rule running, at the moment of decision, has, for reasons which will become apparent, been labeled "pure prospectivity." Neither the litigant in the case announcing the new rule, nor any other person whose claim is based on prior events, will be subject to that rule. ${ }^{29}$ Since the new rule plays no role in determining the outcome of the litigation, it is technically dicta and, as such, communicates only a prediction of what the law will be. ${ }^{30} \mathrm{~A}$ court might even postpone the moment that the rule becomes applicable to some date further in the future. This variation has been called "prospective-prospective overruling." A court may reason that parties affected by the new rule need additional time to adjust their behavior. So, when the Wisconsin Supreme Court abrogated the doctrine of governmental immunity from tort liability on June 5, 1962, it held the "effective date of the abolition of the rule" would be July 15, 1962 in order "[t]o enable the various public bodies to make financial arrangements to meet the new liability." 31 When later, the same year, the Minnesota Supreme Court reached a similar conclusion, it expressed its "intention to overrule the doctrine ... with respect to tort claims ... arising after the next Minnesota Legislature adjourns, subject to any statutes which now or hereafter limit or regulate the

28. Kelly v. Stop \& Shop, Inc., 918 A.2d. 249, 265 n.9 (Conn. 2007). Humphrey v. Great Atl. \& Pac. Tea Co. 993 A.2d 449 (Conn. 2010) modified this formula. See infra note 44.

29. James B. Beam, 501 U.S. at 536. For a recent example see Barnett v. First National Insurance Co. of America, 110 Cal. Rptr. 3d 99, 104 (Cal. Ct. App. 2010) (declining to apply new rule to parties before the court).

30. Walter V. Schaefer, Prospective Rulings: Two Perspectives, 1982 Sup. CT. Rev. $1,22(1982)$.

31. Holytz v. City of Milwaukee, 115 N.W.2d 618, 626 (Wis. 1962). The court presumably was thinking of the time it would take to secure adequate insurance. The next year, when the same court abolished the immunity of religious institutions, it postponed the effect of its holding for three months. Widell v. Holy Trinity Catholic Church, 121 N.W.2d 249, 254 (Wis. 1963). In both cases, however, the plaintiff in the case at bar was allowed to recover. 
prosecution of such claims." This both allowed institutions to buy liability insurance and gave the legislature a chance to craft a different liability regime that would accommodate the special interests of the public entities. ${ }^{32}$

"Purely" prospective judgments are relatively infrequent. Much more commonly a court applies the new rule to the litigants in the instant case but "then returns to the old one with respect to all other[] [cases] arising on facts predating the pronouncement." This course is sometimes called "selective prospectivity." 33 It is, in part, motivated by a desire to connect a judgment's statements of law to the particular controversy before the court. ${ }^{34}$ More prominent is the worry that not granting the benefit of the new rule to the party arguing for it in the case in which it is announced would discourage other litigants from advancing claims that would change existing law. It would, therefore, deprive the legal system of the law-reform benefits deriving from judicial consideration of those claims. ${ }^{35}$ Critics have questioned this premise. The fact that courts maintain retroactive application in the great majority of cases is enough to motivate most litigants. Some parties, moreover, will have a continuing interest in the legal rule so that even if they fail to benefit in the first case, they will profit from its adoption in future ones. ${ }^{36}$

In addition to doubts about its incentive effect, critics of selective prospectivity emphasize the inevitable resulting inequity. ${ }^{37}$ The best known example is the 1959 decision of the Supreme Court of Illinois in Molitor v. Kaneland Community Unit District 302. ${ }^{38}$ The plaintiff was one of fourteen schoolchildren suffering burns and other injuries when, due to the negligence of its driver, a school bus struck a culvert and exploded. ${ }^{39}$ The Supreme Court used the case to reconsider and abolish the tort immunity of school districts. ${ }^{40}$ Since, however, retrospective application of the decision would work a hardship on school districts that may have failed to secure adequate insurance or to investigate prior accidents on the assumption they could not be held

32. Spanel v. Mounds View Sch. Dist. No. 621, 118 N.W.2d 795, 803-04 (Minn. 1962). See also Smith v. State, 473 P.2d 937, 950 (Idaho 1970) (tort liability of state would "govern all future causes of action arising on or after 60 days subsequent to the adjournment of the First Regular Session of the Forty-First Idaho State legislature unless legislation is enacted at that session with respect to the abolition of the sovereign immunity of the state.").

33. James B. Beam, 501 U.S. at 536-37.

34. See EisenBerG, supra note 21 at 131.

35. See Gil J. Ghatan, The Incentive Problem with Prospective Overruling: A Critique of the Practice, 45 Real Prop. Tr. \& Est. L.J. 179, 180-81. See also Fletcher, supra note 7, at 1276.

36. See Candler S. Rogers, Perspectives on Prospective Overruling, 36 U. Mo. Kan. City L. REv. 35, 49 (1968).

37. EISENBERG, supra note 21, at 129.

38. 163 N.E.2d 89 (Ill. 1959).

39. Id. at 89 .

40. Id. at 90-98. 
responsible for them, it decided that the new liability would apply only in "cases arising out of future occurrences." It made an exception, however, for "the plaintiff in the instant case." 41 The unattractive consequences of this solution became apparent when seven other children hurt in the same accident-including three of the first plaintiff's siblings-sought relief. ${ }^{42}$ The trial court, relying on the Supreme Court's explicit exception for only "the plaintiff in the instant case," dismissed the other complaints. The Supreme Court reversed since it "now appears the [first] appeal was treated by [all] the parties as a test case ...."43 The facts of this litigation highlight the arbitrary quality of selective prospectivity. The Court's second decision eliminated the inequity for those involved in the same accident but left in place the different treatment accorded every other victim of municipal negligence who was injured before the date of the first decision. ${ }^{44}$

\section{B. Federal Courts}

Despite these concerns, most state courts maintain the option of non-retroactivity. The situation in federal courts is more complicated. After an initial period of infrequent and unreflective use of non-retroactivity, the United States Supreme Court systematized its approach in 1971 by articulating the three-factor Chevron Oil test cited above for deciding whether to apply a judgment non-retroactively. Then, in the early 1990s, the Supreme Court reversed course and held that federal courts must always apply their judgments retroactively. The following is a brief summary of that evolution.

A set of cases in the nineteenth century recognized-indeed, appeared to require-non-retroactive application of judge-made changes in state law insofar as that law was applied in federal court litigation founded on "diversity jurisdiction," providing a federal forum where the parties to a controversy resided in different states. ${ }^{45}$ At that time, federal judges in diversity cases developed and applied

41. Id at $97-98$

42. Molitor v. Kaneland Comty. Unit Dist. 302, 182 N.E.2d 145, 146-47 (Ill. 1962).

43. Id. at $145-46$.

44. See also Humphrey v. Great Atlantic \& Pacific Tea Co., 993 A.2d 449 (Conn. 2010), in which the Connecticut Supreme Court modified its statement in Kelly $v$. Stop \& Shop, Inc., 918 A2d. 249, 265 n.9 (Conn. 2007)-discussed at supra note 28that an expanded rule of tort liability would apply only to future cases and "previously filed cases in which trial ha[d] not commenced" on the date of decision. In Humphrey, the Court agreed that the new rule should also apply to cases where trial had begun and the plaintiff had raised at trial the same claim as that later adopted in Kelly. The Court was unwilling to sustain differences occasioned by the happenstance that one case had reached it before the other. Humphrey, $993 \mathrm{~A} .2 \mathrm{~d}$ at 453.

45. U.S. Const. art. III, § 2. 
their own federal common law, ${ }^{46}$ but deferred to state courts' interpretations of enacted state law, i.e. statutes and constitutions. In an 1847 diversity case, appealed from the federal court in Mississippi, however, the Supreme Court decided to defer only prospectively to the state court's interpretations of enacted state law. ${ }^{47}$ The Supreme Court had previously held, in the absence of any state court interpretation on point, that a provision of the Mississippi constitution prohibiting the sale of slaves was ineffective without state implementing legislation. After the contract at issue had been made, however, the Supreme Court of Mississippi held the provision selfexecuting. ${ }^{48}$ The United States Supreme Court agreed that federal courts should conform to state court interpretations "from the time they are made. But we ought not to give them a retroactive effect, and allow them to render invalid contracts entered into with citizens of other States, which in the judgment of this court were lawfully made." 49 The dissenting opinion highlighted the anomaly of such a holding, arguing that it "gives to the Constitution of Mississippi different meanings at different periods of its existence ...." 50 The majority's approach was followed in several other federal diversity cases dealing with the validity of bonds issued by local governments under an authority that had first been confirmed by decisions of the state courts but subsequently denied under changed interpretations of state constitutions. ${ }^{51}$

The underlying concern about the unfairness of retroactive decisions evident in these cases, as well as in the state court decisions already canvassed, also surfaced in connection with federal court judgments applying federal law. On three occasions in the $1960 \mathrm{~s}$, perhaps influenced by its decisions refusing to apply new rules of criminal procedure retroactively, ${ }^{52}$ the Supreme Court gave its holdings only prospective effect. 53 Only in the 1971 case of Chevron Oil Co. v. Huson, however, did the modern Supreme Court consider the

46. See Swift v. Tyson, 41 U.S. (16 Pet.) 1 (1842). This policy was reversed in Erie Railroad Co. v. Tompkins, 304 U.S. 64 (1938) holding that federal courts in diversity cases must apply the common law of the state where the court sits.

47. Rowan v. Runnels, 46 U.S. (5 How.) 134, 139 (1847).

48. Id. at 134-35.

49. Id. at 139 .

50. Id. at 140 (Daniel, J., dissenting).

51. See, e.g., Gelpcke v. City of Dubuque, 68 U.S. 175 (1863); Douglass v. County of Pike, 101 U.S. 677 (1879). See also Kuhn v. Fairmont Coal Co., 215 U.S. 349 (1910). See generally Barton $\mathrm{H}$. Thompson Jr., The History of the Judicial Impairment "Doctrine" and Its Lessons for the Contract Clause, 44 StAN. L. REv. 1373 (1992).

52. See infra Part III.B.

53. Two cases avoided invalidating completed elections. Cipriano v. City of Houma, 395 U.S. 701, 706 (1969); Allen v. State Bd. of Elections, 393 U.S. 544, 572 (1968). The third involved a rule of federal jurisdiction where the litigants had reasonably relied on an alternative interpretation. England v. La. State Bd. of Med. Exam'rs, 375 U.S. 411, 422-23 (1964). 
issue of prospectivity in depth. ${ }^{54}$ The plaintiff had sustained a personal injury while at work on Chevron's off-shore drilling platform. Recovery for such claims was governed by a federal statute, the Outer Continental Shelf Land Act, which specified no statute of limitations. Most courts that had addressed the issue had held that the limitations period was controlled by the equitable doctrine of laches. ${ }^{55}$ Then, in a 1969 decision, after Huson had filed his complaint, the Supreme Court rejected those cases and interpreted the Act to borrow the neighboring state's personal injury limitations period. ${ }^{56}$ For $\mathrm{Hu}$ son, that was Louisiana and its one year statute of limitations barred his claim. ${ }^{57}$ The Court held, however, that its 1969 decision "should not be invoked to require application of the Louisiana time limitation retroactively to [Huson]." 58 It went on to elaborate the three criteria already mentioned: (i) the rule had to be genuinely new; (ii) retroactive application was not necessary to further the operation of that rule; and (iii) retroactivity "could produce substantial inequitable results."59 In this case, each factor favored prospective-only application. ${ }^{60}$ Eight Justices joined the opinion. ${ }^{61}$ As already noted, the Chevron Oil test soon became the standard way of deciding prospectivity questions in state courts. ${ }^{62}$

Three decisions in the early 1990s, however, rejected the Chevron Oil test in federal courts. By this time, the Supreme Court, as will be discussed below, had retreated from the idea that it could limit the retroactive effect of decisions creating new constitutional rules of criminal procedure. ${ }^{63}$ Each decision addressed whether taxpayers were entitled to a refund of state taxes paid under a statute later held unconstitutional. In the first, the Supreme Court held that taxpayers were not entitled to a full refund. ${ }^{64}$ Four justices applied the Chevron Oil test, observing that state authorities had reasonably supposed the taxes valid when imposed and that refunds "could deplete the state treasury [and] threaten[ ] the State's current operation and future plans." 65 Four dissenting Justices, however, objected to the idea that courts could apply two different laws to identical controversies simply because they arose at different times. ${ }^{66}$

54. 404 U.S. 97 (1971)

55. Id. at 98-99.

56. Rodrigue v. Aetna Cas. \& Sur. Co., 395 U.S. 352 (1969).

57. Chevron Oil, 404 U.S. at 99.

58. Id. at 100 .

59. Id. at $106-07$.

60. Id. at 107 .

61. Justice Douglas concurred without reaching the question of retroactive effect. Id. at 109 .

62. See supra text accompanying notes 25-27.

63. See infra text accompanying notes 137-46.

64. Am. Trucking Ass'ns, Inc. v. Smith, 496 U.S. 167 (1990).

65. Id. at 182 (opinion of O'Connor, J.).

66. Id. at 205-06 (Stevens, J., dissenting). 
They read Chevron Oil narrowly, claiming that it did not "alter the principle that consummated transactions are analyzed under the best current understanding of the law at the time of decision . . . "67 The Court denied the refunds because the ninth judge, Justice Scalia, believed the state tax in question had been and continued to be constitutional. ${ }^{68}$ But he made clear that he agreed with the dissenters on prospectivity. "Since the Constitution does not change from year to year; since it does not conform to our decisions, but our decisions are supposed to conform to it; the notion that our interpretation of the Constitution in a particular decision could take prospective form does not make sense." 69

The writing was now on the wall. The next year, in the second unconstitutional state tax case, the Court issued five separate opinions, none with the support of more than three justices. But again there were five votes for the proposition that, when the Court decided a constitutional issue and applied it to the parties at bar, it must apply that holding to any other cases still open. ${ }^{70}$ Finally, in the third case, the Court produced a single majority opinion expressing the new understanding:

When this Court applies a rule of federal law to the parties before it, that rule is the controlling interpretation of federal law and must be given full retroactive effect in all cases still open on direct review and as to all events, regardless of whether such events predate or postdate our announcement of the rule. . . .71

Although it expressed a view of adjudication hostile to any form of non-retroactivity, the majority opinion forbade only "selective prospectivity," in which a court applies the new rule to the parties before it but not to other conduct predating the court's judgment. It did not, therefore, overrule Chevron Oil, which was an instance of "pure prospectivity" since the plaintiff had been given the benefit of the previous limitations period. ${ }^{72}$ The Ninth Circuit Court of Appeals recently held that, in the absence of explicit overruling, it was still

67. Id. at 222 .

68. Id. at 204-05 (Scalia, J., concurring in the judgment).

69. Id. at 201 .

70. James B. Beam Distilling Co. v. Georgia, 501 U.S. 529, 543-44 (1991) (opinion of Souter, J.), 548-49 (Scalia, J., concurring in the judgment).

71. Harper v. Va. Dep't of Taxation, 509 U.S. 86, 97 (1993).

72. In 1995 , seven justices joined an opinion stating that "Harper [the third tax case] overruled Chevron Oil insofar as the case (selectively) permitted the prospective-only application of a new rule of law." Reynoldsville Casket Co. v. Hyde, 514 U.S. $749,752(1995)$ 
bound to apply new rules purely prospectively when the three Chevron Oil factors so required. ${ }^{73}$

The Supreme Court's decisions retreating from prospective judgments show the influence of the factors already discussed that have worried courts and commentators about the practice. A central complaint was its deviation from the judicial role. This concern reflected, at some level, the Blackstonian view of adjudication. It was most explicit in the separate opinions of Justice Scalia. The judge's job, he asserted, "is to say what the law is, not to prescribe what it shall be.... [A prospective holding] presupposes a view of our decisions as creating the law, as opposed to declaring what the law already is." "74 Closely related to this was possible violation of the constitutional imperative that federal courts adjudicate only real "cases or controversies." 75 It has been argued that this precludes a federal court pronouncing on a legal issue unnecessary to resolve the dispute at bar. ${ }^{76}$ This argument is doubtful as a matter of constitutional interpretation, 77 but the Supreme Court had appeared to accept it in an earlier criminal procedure case in which it had declined to apply a new rule retroactively though it conceded that it had applied it to the parties in the case first announcing it. In that first case, however, retroactive application was an "unavoidable consequence of the necessity that constitutional adjudications not stand as mere dictum [and of] [s] ound policies of decision-making, rooted in the command of Article III of the Constitution that we resolve issues solely in concrete cases or controversies . ..."78

If the limits of constitutional federal jurisdiction obliged a federal court to apply a new rule to the party in the case announcing it, then the only kind of prospectivity available to it was "selective prospectivity." The Supreme Court, however, became unwilling to accept the inequity of making the applicability of a rule turn solely on which litigant happened to reach the Court first. ${ }^{79}$ In an earlier case, Justice Harlan had protested the consequences of this policy:

73. Nunez-Reyes v. Holder, 646 F. 3d 684, 690-95 (9th Cir. 2011). See also Jill E. Fisch, Retroactivity and Legal Change: An Equilibrium Approach, 110 Harv. L. REv. 1055, 1062 (1997).

74. Am. Trucking Ass'ns, Inc. v. Smith, 496 U.S. 167, 201 (1990) (Scalia, J., concurring in the judgment); James B. Beam, 501 U.S. at 549 (Scalia, J., concurring); Harper, 509 U.S. at 106-07 (Scalia, J., concurring). See infra text accompanying notes 192-96.

75. U.S. Const. art. III, $\S 2$, cl. 1.

76. Note, supra note 24 , at 932 .

77. See Currier, supra note 21 , at 216-20.

78. Stovall v. Denno, 388 U.S. 293, 300-01 (1967). See Kermit Roosevelt III, A Little Theory Is a Dangerous Thing: The Myth of Adjudicative Retroactivity, 31 ConN. L. REv. 1075, 1111-12 (1999).

79. See Bradley Scott Shannon, The Retroactive and Prospective Application of Judicial Decisions, 26 Harv. J. L. \& Pub. Pol'y 811, 866 (2003). 
Simply fishing one case from the stream of appellate review, using it as a vehicle for pronouncing new constitutional standards, and then permitting a stream of similar cases subsequently to flow by unaffected by that new rule constitute an indefensible departure from this model of judicial review. 80

These arguments, which had already convinced a majority of the Court in the field of criminal procedure, ultimately led to a policy of "full retroactivity" in the adjudication of federal civil cases. ${ }^{81}$

It is important to remember that the development just traced is applicable only to changes in federal law. As already noted, state courts applying state law retain the option of prospective-only effect when declaring new rules. Such a practice, moreover, continues to be constitutionally permissible under the rule of Great Northern Railway. Co. v. Sunburst Oil \& Refining Co. ${ }^{82}$ These courts have generally rejected the reasoning of the United States Supreme Court's post-Chevron Oil cases. Indeed, the Chevron Oil analysis remains the most common test in state jurisdictions for deciding whether to apply a new rule retroactively. ${ }^{83}$ When, however, state courts apply a new judge-made rule of federal law, the Supremacy Clause of the federal Constitution requires that they apply it retroactively in accordance with the holdings of the United States Supreme Court. ${ }^{84}$

\section{The Limits of Retroactivity}

There are necessary limits to the presumptive retroactive application of judicial pronouncements. Although the United States Supreme Court has said that "a rule of federal law, once announced and applied ... must be given full retroactive effect by all courts adjudicating federal law," it restricts that command to "cases still open on direct review." 85 No one suggests that a new rule requires courts to re-open and re-decide every case ever litigated to which a new rule might apply. A rule's retroactivity does not extend to cases that have proceeded to:

80. Mackey v. United States, 401 U.S. 667, 679 (1971) (Harlan, J., concurring and dissenting).

81. Harper v. Va. Dep't of Taxation, 509 U.S. 86, 97 (1993).

82. 287 U.S. 358 (1932).

83. Some recent examples are Heritage Farms, Inc. v. Markel Ins. Co., 810 N.W.2d 465, 479-80 (Wis. 2012); Beaver Excavating Co. v. Testa, 983 N.E.2d 1317, 1328 (Ohio 2012); Bezeau v. Palace Sports \& Ent., Inc., 795 N.W.2d 797, 802 (Mich. 2010); Ex parte Capstone Bldg. Corp. 96 So. 3d 77, 90-95 (Ala. 2012).

84. Reynoldsville Casket Co. v. Hyde, 514 U.S. 749, 754 (1995); Harper, 509 U.S. at 100 .

85. Harper, 509 U.S. at 96,97 
such a degree of finality that the rights of the parties should be considered frozen. ... [T] hat moment should be when the transaction is beyond challenge either because the statute of limitations has run or the rights of the parties have been fixed by litigation and have become res judicata. ${ }^{86}$

In Chicot County Drainage District v. Baxter State Bank, 87 bondholders whose rights had been reduced under a federal statute subsequently declared unconstitutional sought to recover the full amount originally due. The Supreme Court noted that a 1936 District Court proceeding-in which the validity of the governing law was not raised-had confirmed the prior adjustment and had never been appealed. ${ }^{88}$ The law's constitutionality was thus res judicata and could not be raised in a collateral proceeding. ${ }^{89}$ As the Court put it in a later case, "the res judicata consequences of a final, unappealed judgment on the merits [are not] altered by the fact that the judgment may have been wrong or rested on a legal principle subsequently overruled in another case."90

The limits of retroactivity are grounded in strong practical policy. "A contrary rule," as one state court noted, "would produce chaos in the legal system, as judgments could be continually opened and reopened with every fluctuation in the law."91 A nineteenth century Supreme Court decision put the matter powerfully:

[T] he maintenance of public order, the repose of society, and the quiet of families, require that what has been definitely determined by competent tribunals shall be accepted as irrefragable legal truth. So deeply is this principle implanted in [our] jurisprudence, that commentators upon it have said, that res judicata renders white that which is black, and straight that which is crooked. ${ }^{92}$

The policy of finality in civil litigation, however, is not absolute. In rare cases, parties may collaterally attack otherwise final judgments-but only if the case is truly exceptional. Both the

86. United States v. Estate of Donnelly, 397 U.S. 286, 296 (1970) (Harlan, J., concurring). See also James B. Beam Distilling Co. v. Georgia, 501 U.S. 529, 541 (1991) (opinion of Souter, J.)

87. 308 U.S. 371 (1940).

88. Id. at $372-74$.

89. $I d$. at 378 .

90. Fed. Dep't Stores, Inc. v. Moitie, 452 U.S. 394, 398 (1981).

91. Quantum Res. Mgm't, L.L.C. v. Pirate Lake Oil Corp., 112 So. 3d 209, 217 (La. 2013), cert. denied sub nom. Haydel v. Zodiac Corp., 134 S. Ct. 197 (2013). The complainants had asked to re-open a 1925 tax sale on the basis of a 1983 United States Supreme Court decision. 112. So. 2d 217.

92. Jeter v. Hewitt, 63 U.S. (22 How.) 352,364 (1859). The Court was commenting on the doctrine as adopted in Louisiana but, as one commentator noted, it would "apply with equal truth to any of the United States." 2 Henry Campbell Black, A Treatise on the LAW OF JudGMents 764 (1902). 
Restatement (Second) of Judgments and the Federal Rules of Civil Procedure articulate such a possibility.

Section 73(2) of the Restatement states that a judgment "may be set aside or modified if . . . "[t]here has been such a substantial change in the circumstances that giving continued effect to the judgment is unjust." Noting that this principle has sometimes been applied to cases where a later decision changed the law applied in an earlier, unrelated judgment, however, Comment (c) to this section labels such decisions "a misinterpretation of the rule and a very unsound policy."93

Rule 60(b) of the Federal Rules of Civil Procedure specifies five grounds for "relief from a final judgment" none of which speak directly to a change in the governing law. A sixth refers to "any other reason that justifies relief." The rare cases in which the Supreme Court has considered applying Rule 60(b)(6) in connection with a change in the law are inconclusive. ${ }^{94}$ One judge has described Rule $60(b)(6)$ jurisprudence as showing "a strong current of unwillingness to reopen judgments but with some wriggle room for future arguments." 95 Still, other lower federal courts have referred to the rule as "a grand reservoir of equitable power," 96 and have assumed that an "intervening change of controlling law" may justify exercising it. ${ }^{97}$ In practice, this kind of relief is very unusual. Whenever courts note the possibility of modifying a final judgment, they always stress the need to show particularly compelling reasons. Notwithstanding the occasional exception, it is fair to say that the presumptive-and in federal courts nearly compulsory-retroactive effect of civil judgments reaches back only to controversies still open to judicial resolution. At some point adjudication comes to an end and unsuccessful civil litigants are denied the solace of newer and friendlier law.

In criminal cases, where a defendant remains in custody, however, the finality of a conviction is not so unqualified. The continuing possibility of collateral attack has been critical in shaping the law of the retroactivity and prospectivity of judicial decisions. This is the subject of the next section.

93. Restatement (SeCOND) of Judgments $\$ 73(2)$, cmt. c.(1982).

94. Compare Ackermann v. United States, 340 U.S. 193, 198 (1950) with Polites v. United States, 364 U.S. 433 (1960).

95. Norgaard v. DePuy Orthopaedics, Inc., 121 F.3d 1074, 1078 (7th Cir. 1997) (Easterbrook, Cir. J.). This decision contains an extended argument for a strict interpretation of Rule $60(\mathrm{~b})(6)$ when the motion to modify a judgment is based on a subsequent change in the law.

96. Radack v. Norwegian Am. Line Agency, Inc., 318 F.2d 538, 542 (2d. Cir. 1963).

97. Marrero Pichardo v. Asheroft, 374 F.3d 46, 56 (2d Cir. 2004). 


\section{Prospective Judgments in Criminal Law}

\section{A. Substantive Liability}

Discomfort with retroactive law has been most acute in connection with retroactive criminal liability. The United States Constitution explicitly prohibits all ex post facto criminal laws. ${ }^{98}$ The values underlying these worries are not entirely clear. The reliance interest, so prominent in civil prospectivity jurisprudence, may play a role if an actor is likely to consult the criminal law before acting. But criminal acts, like most tortious acts, are seldom the subject of selfconscious reliance on the law. ${ }^{99}$ The objection to ex post facto criminality seems premised on some more rudimentary sense of fairness. ${ }^{100}$

The Supreme Court has held that the constitutional limitation on "ex post facto laws" refers only to legislation; not to judicial acts. ${ }^{101}$ This presents few problems when judicial action contracts the scope of criminal behavior. When a criminal statute is held unconstitutional, even a final judgment of conviction is deemed void and may be subject to collateral attack. ${ }^{102}$ More serious issues arise when courts interpret criminal law to reach acts that appeared lawful when committed. Such cases seem to raise problems identical to those underlying the ban on ex post facto legislation. As a result, courts have tried to find ways to apply these new interpretations only prospectively. ${ }^{103}$ In State $v$. Jones, for example, the Supreme Court of New Mexico changed its construction of the statute forbidding lotteries. ${ }^{104}$ The defendants' previous conviction for holding a "bank night" promotion at a movie theater had been reversed by the Supreme Court that held that such events were not lotteries. ${ }^{105}$ But when they were prosecuted a second time for the same offense, the Supreme Court rejected its former interpretation and held that bank nights were lotteries. Since, however, the defendants "did only that which this court declared, even if erroneously, to be within the law" the "plainest principles of justice" demanded that the new interpretation should be given only prospective effect. The court declared that its new view of the statute would be observed only "in cases having their origin in

98. U.S. Const. art I, $\S 9$, cl. 3 (federal); $i d$. art. I, $\S 10$, cl. 1 (states).

99. Harold J. Krent, The Puzzling Boundary Between Criminal and Civil Retroactive Lawmaking, 84 GEO. L.J. 2143, 2160-63 (1996).

100. See Traynor, supra note 20 , at 548-49.

101. See note 9 supra.

102. See Traynor, supra note 20, at 553 n.54 (citing Ex parte Siebold, 100 U.S. 371, 376-77 (1879).

103. See Rogers, supra note 36 , at 64.

104. 107 P.2d 324 (N.M. 1940).

105. Id. at 325 . 
acts and conduct occurring subsequent to the effective date of this decision."106

The Supreme Court of the United States dealt with a similar problem in James $v$. United States, a prosecution for tax evasion based on the defendant's failure to report embezzled funds as income. ${ }^{107}$ An earlier case, Commissioner v. Wilcox, had held that embezzled funds were not income for these purposes. ${ }^{108}$ Three justices thought Wilcox continued to be good law and would have dismissed the prosecution on that basis. ${ }^{109}$ Three different justices would have overruled Wilcox and remanded for a new trial. ${ }^{110} \mathrm{~A}$ third set of three justices would have overruled Wilcox but also dismissed this case because the existence of the Wilcox holding made it impossible to attribute to the defendant the "willfulness" necessary to sustain a conviction. ${ }^{111}$ The net result of this division was that the Court overruled Wilcox but did not apply its new interpretation to the case before it or to any tax returns filed before the date of the decision. ${ }^{\mathbf{1 1 2}}$

It should be noted, however, that six justices in the James case rejected the idea that the Court could apply its interpretation of the criminal law prospectively only. In his separate opinion, Justice Black dismissed the idea of prospective overruling but also thought that any criminal statute so ambiguous as to be susceptible of an entirely unexpected interpretation would "raise[ ] serious questions of unconstitutional vagueness." 113 The Court applied that reasoning in Bouie v. City of Columbia. ${ }^{114}$ The South Carolina Supreme Court had adopted a new and surprising interpretation of the state's criminal trespass law to sustain the conviction of civil rights demonstrators conducting a "sit-in" at a segregated lunch counter. ${ }^{115}$ The United States Supreme Court held that this "unforeseeable and retroactive judicial expansion of narrow and precise statutory language" was a "deprivation of the right of fair warning." Such an interpretation, if "applied retroactively, operates precisely like an ex post facto law ... . If a state legislature is barred by the Ex Post Facto Clause from passing such a law, it must follow that a State Supreme Court is

106. Id. at 329 .

107. 366 U.S. 213 (1961).

108. 327 U.S. 404,410 (1946).

109. James, 366 U.S. at 248 (Whittaker, J., concurring in part and dissenting in part).

110. Id. at 241 (Clark, J., concurring in part and dissenting in part); id. (Harlan, J., concurring in part and dissenting in part).

111. Id. at 221-22 (opinion of Warren, C.J.).

112. Id. at 222 .

113. Id. at 224-25 (Black, J., concurring in part and dissenting in part).

114. 378 U.S. 347 (1964).

115. Id. at 349-50. 
barred by the Due Process Clause from achieving precisely the same result by judicial construction."116

\section{B. New Constitutional Rules of Criminal Procedure}

While American courts generally apply reductions in criminal liability retroactively and enlargements of that liability only prospectively, the rules governing application of changes in criminal procedure are much more complicated. In the early 1960s, the United States Supreme Court decided a number of cases dramatically enlarging the rights of criminal defendants, including the right to counsel, ${ }^{117}$ to remain silent, ${ }^{118}$ to fair procedures in identification by witnesses, ${ }^{119}$ and to exclude improperly secured evidence. ${ }^{120}$ The cumulative effect has more than once been described as a "revolution."121 Judged under these new constitutional standards, many prior convictions would be invalid. During the same period, the Supreme Court also expanded the opportunities to attack a constitutionally defective state court conviction in federal court through a petition for a writ of habeas corpus. ${ }^{122}$

These developments were ominous for a regime of thorough retroactivity. Thousands of incarcerated people were now in a position to reopen and possibly reverse their criminal convictions. One obvious solution was to hold the new rules of criminal procedure were at least partly non-retroactive. The issue came before the Supreme Court in 1965 in Linkletter $v$. Walker. ${ }^{123}$ Three years before, in Mapp v. Ohio, the Court had held that the Fourth Amendment made improperly seized evidence inadmissible in criminal prosecutions in state

116. Id. at 352-54 (citing Jerome Hall, General Principles of Criminal Law 61 (2d ed. 1960)). See also Marks v. United States, 430 U.S. 188 (1977) (reversing obscenity conviction that was unconstitutional under the First Amendment case law prevailing at the time of the trial even though the conviction might have been constitutional under a subsequently adopted standard in force at the time of the Supreme Court's decision). The Court qualified its decision in Bouie in Rogers v. Tennessee, 532 U.S. 451 (2001) in which it upheld a conviction based on the state court's decision to abandon the common law "year and a day" defense to homicide prosecution. The Court denied that identical limits constrained legislation and judicial interpretation. This was especially true for the application of common law rules that "presuppose[ ] a measure of evolution that is incompatible with stringent application of ex post facto principles." Id. at 461-62.

117. Gideon v. Wainwright, 372 U.S. 335 (1963).

118. Miranda v. Arizona, 384 U.S. 436 (1966)

119. United States v. Wade, 388 U.S. 218 (1967)

120. Mapp v. Ohio, 367 U.S. 643 (1961).

121. See Yale Kamisar, The Warren Court and Criminal Justice: A Quarter Century Retrospective, 31 TuLSA L.J. 1 (1995).

122. See, e.g., Fay v. Noia, 372 U.S. 391 (1963) (holding that failure to raise a constitutional claim in state proceedings did not preclude habeas relief in federal court). Under the current statute, habeas corpus is available for persons "in custody in violation of the Constitution or laws or treaties of the United States." 28 U.S.C. \$ 2254(a). 123. 381 U.S. 618 (1965). 
courts. ${ }^{124}$ Linkletter was convicted of burglary in Louisiana in 1959 based, in part, on evidence subsequently held to be illegal. The state Supreme Court affirmed his conviction in 1960. After the decision in Mapp, Linkletter petitioned in federal court for a writ of habeas corpus. The United States Supreme Court held that the rule of Mapp was not fully retroactive. ${ }^{125}$ The Court cited some of the civil cases discussed above in Part II for the proposition that "the Constitution neither prohibits nor requires retrospective effect." "[W]e must . . . weigh the merits and demerits in each case by looking to the prior history of the rule in question, its purpose and effect, and whether retrospective operation will further or retard its operation." 126 Since Mapp was intended only as a "deterrent to lawless police action" its purpose would not be "advanced by making the rule retrospective." Past police misconduct could not be undone "by releasing the prisoners involved."127 Moreover, states' reliance on prior law was due the same respect that private reliance was given when new rules changed civil liability. ${ }^{128}$ Given the number of potential petitioners, retroactive application "would tax the administration of justice to the utmost." 129

The Court later rephrased the proper approach in a formula:

The criteria guiding resolution of the question implicates (a) the purpose to be served by the new standards, (b) the extent of the reliance by law enforcement authorities on the old standards, and (c) the effect on the administration of justice of a retroactive application of the new standards. ${ }^{130}$

Linkletter itself denied retroactive application only to cases that were already final when the new rule was announced. ${ }^{131}$ In Stovall $v$. Denno, however, the Court held that a new rule, excluding evidence of a police-arranged eyewitness identification in the absence of counsel, would affect only confrontations occurring after the new rule had been announced. ${ }^{132}$ Thus, it would apply neither to final cases nor to some cases still open on direct review. The underlying reasons for non-retroactivity provided no basis to distinguish between final con-

124. 367 U.S. 643,660 (1961)

125. Linkletter, 381 U.S. at 640.

126. Id. at 629 .

127. Id. at 636-37.

128. See id. For a criticism of this equation, see Paul J. Mishkin, Foreword: The High Court, the Great Writ, and the Due Process of Time and Law, 79 Harv. L. REv. $56,73-74(1965)$.

129. Linkletter, 381 U.S. at 637.

130. Stovall v. Denno, 388 U.S. 293,297 (1967).

131. 381 U.S. at 622.

132. 388 U.S. at 296. 
victions and those still "at various stages of trial and direct review."133

In subsequent cases, the Court set various effective dates for the applicability of new rules of criminal procedure. A rule excluding a defendant's statements made without adequate warnings about the right to counsel applied only to cases in which the trial began after the new rule was announced. ${ }^{134}$ The holding that electronic surveillance was a "search" or "seizure" subject to the Fourth Amendment applied only to cases in which the surveillance was undertaken after the relevant judgment. ${ }^{135}$ New rules on permissible searches incident to arrest applied only to searches occurring after the promulgation of those rules. ${ }^{136}$

This era of prospectivity, however, was short-lived. Starting in the late 1960s, Justice Harlan, who had joined some of the early opinions, issued a series of powerful dissents to the Court's decisions. He objected to a perceived departure from the Court's judicial role and was especially offended by the Court's record of what we have called "selective prospectivity." Typically, the Court decided the constitutional question in one case, applying its new rule-necessarily retroactively - to the parties at bar. It only addressed the retroactivity question when another party raised it in a later case. Deciding the new rule was only prospective at that point resulted in an intolerable inequity. ${ }^{137}$ Justice Harlan, therefore, advocated the full retroactivity of constitutional judgments for all cases not yet final in the sense that the defendants had exhausted all available appeals. ${ }^{138}$

A majority of the Court adopted his arguments after Justice Harlan had left the bench. The 1982 case of United States v. Johnson $^{139}$ concerned the retroactivity of a 1980 decision $^{\mathbf{1 4 0}}$ holding that the Fourth Amendment prohibits warrantless entry into a residence

133. Id. at 300 .

134. Johnson v. New Jersey, 384 U.S. 719, 721 (1966) (concerning retroactivity of Escobedo v. Illinois, 378 U.S. 478 (1966), and Miranda v. Arizona, 384 U.S. 436 (1966)).

135. Desist v. United States, 394 U.S. 244, 254 (1969) (concerning retroactivity of Katz v. United States, 389 U.S. 347 (1967)).

136. Williams v. United States, 401 U.S. 646, 656 (1971) (plurality opinion) (concerning retroactivity of Chimel v. California, 395 U.S. 752 (1969)). For a summary of the different effective times see Julie R. O'Sullivan, Note, United States. v. Johnson: Reformulating the Retroactivity Doctrine, 69 CoRNELL L.J. 166, 174-75 (1983).

137. See the quotation from Justice Harlan's opinion in Mackey v. United States, reproduced at supra text accompanying note 80 .

138. Mackey v. United States, 401 U.S. 667, 690 (1971) (Harlan, J., concurring and dissenting).

139. 457 U.S. 537 (1982). By this time a substantial critical academic commentary had also developed. See James R. McCall, A Basic Concern for Process: Commentary on Quo Vadis, Prospective Overruling, 50 Hastings L.J. 805, 809 (1999) ("[D]uring the $1970 \mathrm{~s}$. . . scholars were having 'a veritable field day' with the Warren Court's opinions on prospective overruling.").

140. Payton v. New York, 445 U.S. 573 (1980). 
to make a routine arrest. The Court held that its decisions should usually be "applied retroactively to all convictions that were not yet final at the time the decision was rendered."141 In a significant limitation, however, the Court permitted non-retroactive application of new rules that were "clear break[s] with the past." 142 In these cases, "prospectivity [was] arguably the proper course." 143 In 1987, however, in Griffith v. Kentucky, ${ }^{144}$ the Court abandoned this "clear break" exception when it held that a new rule ${ }^{145}$ limiting a prosecutor's ability to use peremptory challenges based on a potential juror's race would apply retroactively notwithstanding its admitted novelty. Current federal law on the retroactivity of new decisions on questions of criminal procedure has thus reverted to the holding of Linkletter $v$. Walker: " $[\mathrm{A}]$ new rule for the conduct of criminal prosecutions is to be applied retroactively to all cases, state or federal, pending on direct review or not yet final . . . ."146

The key moment for cutting off the retroactive effect of judgments announcing new constitutional rules of criminal procedure, therefore, is when a state court conviction has become "final"-i.e., when there is no further opportunity for direct appellate review either in the state courts or by writ of certiorari to the United States Supreme Court. As in civil litigation, this point has been defended by the need to bring proceedings to some identifiable close. There must, Justice Harlan had argued, "be a visible end to the litigable aspect of the criminal process. ... If law, criminal or otherwise, is worth having and enforcing, it must at some time provide a definitive answer to the question litigants present or else it never provides an answer at all."147

Historically, however, res judicata did not shield a final criminal judgment from challenge as fully as it would a final civil judgment. "Because of habeas corpus and similar writs, ... . [a] criminal judgment of conviction does not enjoy the same degree of finality until the defendant has been executed, died in prison, or been released."148 A habeas petition technically initiates a new civil action "for the en-

141. Johnson, 457 U.S. at 562. Ironically, this decision was held not to "affect those cases that would be clearly controlled by our existing retroactivity precedents," making the restoration of the retroactivity rule non-retroactive in a substantial number of cases. $I d$.

142. Id. at 558 .

143. Id. at 559 (quoting Williams v. United States, 401 U.S. 646, 659 (1971)).

144. 479 U.S. 314 (1987).

145. Batson v. Kentucky, 476 U.S. 79 (1986).

146. Griffith, 479 U.S. at 328.

147. Mackey v. United States, 401 U.S. 667, 690-91 (1971) (Harlan, J., concurring and dissenting).

148. Currier, supra note 21, at 258-59. See also 1 WAyne R. LAFAve ET AL., CRIMINal Procedure 864 (3d ed. 2000). 
forcement of the right to personal liberty . . ."149 Expressly limiting "full" retroactive application to cases still "on direct review" was, therefore, essential to avoid potentially re-opening the conviction of every defendant still in custody. Since many of the new criminal procedure rules were concededly unrelated to the merits of a prosecution, applying them retroactively to finally adjudicated convictions would result in the "wholesale release of the guilty." 150 If it did nothing else, this limitation imposed a quantitative limit on the resulting disruption. ${ }^{151}$

Nonetheless, refusing to apply a new rule of criminal procedure to all defendants incarcerated as a result of trials in which that rule had not been observed necessarily involved some arbitrariness. It kept "all people in jail who were unfortunate enough to have had their unconstitutional convictions affirmed before June 19, 1961."152 As the dissent was quick to point out, Linkletter had committed his offense before the defendant in Mapp, who had been released under that case's new exclusionary rule. If the courts had not delayed in resolving Linkletter's appeal, his case would have reached the Supreme Court first and he would have been released under the new exclusionary rule instead. ${ }^{153}$ "Too many irrelevant considerations," noted one commentator, "including the common cold, bear upon the rate of progress of a case through the judicial system."154

Limiting the retroactive effect of new criminal procedure rules to cases on direct review has been defended not so much as a logical feature of retroactivity but as an aspect of the restricted purpose of habeas corpus in federal courts. On this account, habeas exists not to correct errors but to ensure that state courts adhere to applicable federal standards of criminal justice. For this purpose, it generally suffices that criminal prosecutions conform to the law in effect at the time of the trial. 155 The Supreme Court crystallized this approach in 1988 in Teague $v$. Lane. ${ }^{156}$ "The relevant frame of reference," it em-

149. Fay v. Noia, 372 U.S. 391, 423 (1963). In "extraordinary" cases, moreover, even when habeas corpus is not available, a final criminal conviction may be reviewed by application in federal court for a writ of coram nobis. United States v. Denedo, 556 U.S. 904, 916 (2009).

150. Linkletter, 381 U.S. at 637-38. See also Roosevelt, supra note 78, at 1091.

151. See Fallon \& Meltzer, supra note 10 , at 1815 . In this respect, however, consider Justice White's dissent in Shea v. Louisiana, 470 U.S. 51, 64 n.1 (1985) ("[B]y the same token, it would be less burdensome to apply Edwards retroactively to all cases involving defendants whose last names begin with the letter ' $\mathrm{S}$ ' than to make the decision fully retroactive.").

152. Linkletter, 381 U.S. at 641 (Black, J., dissenting).

153. Id.

154. Schaefer, supra note 24 , at 645. See also Shea, 470 U.S. at 63 (White, J., dissenting); Currier, supra note 21, at 202, 259-260; Michael B. Dashjian, The Prospective Application of Judicial Legislation, 24 PAC. L.J. 317, 381 n.352 (1993).

155. See Mackey v. United States, 401 U.S. 667, 684, 687, 691-92 (1971) (Harlan, J., concurring and dissenting); Roosevelt, supra note 78 , at 1093-94.

156. 489 U.S. 288 (1989). 
phasized, "is not the purpose of the new rule whose benefit the [defendant] seeks, but instead the purposes for which the writ of habeas corpus is made available." 157 A rule declared only after a conviction was final could not be relied on in a subsequent collateral proceeding. There were two narrow exceptions. A dissenting Justice summarized them accurately:

Any time a federal habeas petitioner's claim, if successful, would result in the announcement of a new rule of law, ... it may only be adjudicated if that rule would [1] plac[e] certain kinds of primary, private individual conduct beyond the power of the criminal law-making authority to proscribe, or [2] if it would mandate new procedures without which the likelihood of an accurate conviction is seriously diminished. ${ }^{158}$

Although some parts of this analysis commanded the assent of only four justices, a majority of the Court approved it the following year. ${ }^{159}$ Teague's rules are now treated "as the settled guidelines for determining what law applies on habeas review." 160

Teague's restriction on the use of "new rules" on collateral review has been interpreted very broadly. A new rule need not be the kind of "clean break" briefly significant under United States $v$. Johnson. ${ }^{161}$ "[A] case announces a new rule if the result was not dictated by precedent existing at the time the defendant's conviction became final."162 Even though a judgment is carefully and plausibly explained as an application of existing law, it may still be a "new rule." It qualifies, according to a later decision, so long its outcome "was susceptible to debate among reasonable minds." 163 "[A]ny reading beyond the narrowest reasonable reading of [applicable] precedent . . . can readily be viewed as a 'new rule.' "164

This broad understanding of eligible new rules is reinforced by the Court's parsimonious reading of Teague's two exceptions. The first concerned new rules that placed "certain kinds of primary, private individual conduct beyond the power of the criminal law-making authority to proscribe." 165 This falls within the well-established doc-

157. Id. at 306 (quoting Mackey v. United States, 401 U.S. at 682 (Harlan, J., concurring in part and dissenting in part).

158. Id. at 330 (Brennan, J., dissenting) (citations omitted) (internal quotation marks omitted).

159. Penry v. Lynaugh, 492 U.S. 302 (1989).

160. LA FAve, supra note 148 , at 880 .

161. See supra text accompanying notes 139-43.

162. Teague, 489 U.S. at 301.

163. Butler v. McKellar, 494 U.S. 407, 415 (1990). For a recent application, see Chaidez v. United States, 133 S. Ct. 1103 (2013).

164. LA FAvE, supra note 148, at 882.

165. Teague, 489 U.S. at 311 (quoting Mackey v. United States, 401 U.S. 667, 692 (Harlan, J., concurring in part and dissenting in part)). 
trine that decisions narrowing the scope of criminal liability should be fully retroactive. ${ }^{166}$ Therefore, a court recently held that it was proper to reconsider a final unappealed conviction for gun possession after the Supreme Court found the relevant statute unconstitutional. ${ }^{167}$ This exception also allows collateral review when a court reinterprets a criminal statute to exclude a petitioner's conduct. ${ }^{168}$

The second exception permits a habeas court to review an otherwise final conviction if it were obtained in violation of a laterformulated "watershed rule[] of criminal procedure," non-observance of which would result in "the likelihood of an accurate conviction [being] seriously diminished." 169 This exception has turned out to be extremely limited in practice. Such a rule must "alter our understanding of the bedrock procedural elements essential to the fairness of a proceeding." 170 The Court had already recognized that the great bulk of the new procedures mandated in the rights revolution of the 1960 s did not measurably enhance the truth-finding aspects of a criminal prosecution. They were aimed only at deterring unconstitutional police or prosecutorial misconduct. ${ }^{171}$ The Supreme Court has, in fact, identified only one case whose rule would satisfy this criterion-Gideon v. Wainwright, ${ }^{172}$ which mandated legal representation at public expense for indigent defendants. ${ }^{173}$ The Court has declined, on the other hand, to allow a death-row prisoner to challenge his execution collaterally based on a Supreme Court judgment-announced after his sentence holding that an aggravating factor essential to impose the death penalty must be determined by the jury and not the judge. ${ }^{174}$

In 1996, Congress enacted the Antiterrorism and Effective Death Penalty Act. (AEDPA)] ${ }^{175}$ It restricted the right of state court defendants to challenge their convictions by collateral review in federal court, creating, among other requirements, strict time limits. It also specified that, if a particular claim had been "adjudicated on the merits in state court proceedings," a federal court could not issue a writ of habeas corpus unless the state court adjudication "resulted in a decision that was contrary to, or involved an unreasonable application of, clearly established Federal law, as determined by the Supreme Court

166. See supra text accompanying note 102. But see Warring v. Colpoys, 122 F.2d 642,647 (D.C. Cir. 1941).

167. Magnus v. United States, 11 A.3d 237, 243-46 (D.C. 2011). The rehearing was held to be a proper exercise of a court's power to issue a writ of error, coram nobis.

168. Bousley v. United States, 523 U.S. 614, 620-21 (1998).

169. Teague, 489 U.S. at $311,313$.

170. Whorton v. Bockting, 549 U.S. 406, 418 (2007).

171. See e.g. Linkletter v. Walker, 381 U.S. 618, 637 (1965).

172. 372 U.S. 335 (1963).

173. Whorton, 549 U.S. at 419.

174. Schiro v. Summerlin, 542 U.S. 348, 352-56 (2004).

175. Pub. L. No. 104-132, 110 Stat. 1214 (codified in scattered sections of 28 U.S.C.). 
of the United States."176 This requirement roughly mirrors the plurality approach in Teague in that the "clearly established federal law" to which the state court decision must conform is the law at the time of that state court decision; not subsequently declared changes in the required procedures. ${ }^{177}$

The Act and the Court's doctrine are not, however, precisely congruent. For example, the "new rule" that may not be relied on for habeas relief under Teague is one announced after the petitioner's case became final. ${ }^{178}$ But the "clearly established Federal law" to which a state court decision might conform to bar such relief under the statute is that existing at the time of the relevant decision, even if the law was changed before the conviction became final-so that it might have been properly applied in reviewing the decision under Griffith and Teague. ${ }^{179}$ Both sets of limitations-of Teague and of the Act-must be overcome before a federal district court may grant a habeas petition. ${ }^{180}$

The foregoing discussion concerns only the limits of retroactive application of new constitutional rules of criminal procedure in collateral review of state criminal convictions in federal courts. State law also typically allows collateral attacks on convictions even after direct review is no longer available. State courts are free to apply new rules of criminal procedure on such review, even if a federal court could not. ${ }^{181}$ State courts, in fact, apply a range of approaches when deciding whether to apply such law. Many have adopted the federal approach articulated in Teague. ${ }^{182}$ Others have kept the three factor test adopted-and now rejected-by the United States Supreme Court in Linkletter v. Walker and Stovall v. Denno. ${ }^{\mathbf{1 8 3}}$

\section{The Problems of Prospective Adjudication}

As this summary indicates, the history and current status of the once widely accepted idea that judicial pronouncements of law are thoroughly retroactive are complicated and obscure. At present, for civil cases, most state courts applying state law examine the relevant factors favoring or disfavoring prospective application on a case-bycase basis. All courts must apply new rules of federal law to all cases

176. 28 U.S.C. $\S 2254(\mathrm{~d})(1)-(2)$.

177. Lockyer v. Andrade, 538 U.S. 63,71 (2003).

178. Teague v. Lane, 489 U.S. 288, 310 (1989).

179. Greene v. Fisher, 132 S. Ct. 38, 44-45 (2011).

180. Horn v. Banks, 536 U.S. 266, 271(2002) (per curiam), See also LaRRY W. Yackle, Federal Courts: Habeas Corpus 183-200 (2d ed. 2010) (discussing the relationship between the statute and the case law).

181. Danforth v. Minnesota, 552 U.S. 264, 295 (2008).

182. See, e.g., People v. Sanders, 939 N.E.2d 352 (Ill. 2010); Commonwealth v. Cunningham, No. 38 EAP 2012, 2013 WL 5814388 (Pa. Oct. 30, 2013).

183. See, e.g., State v. Knight, 678 A.2d 642, 652 (N.J. 1996). On Linkletter and Stovall, see supra text accompanying notes 123-30. 
still pending on direct review at the time that the rule is declared. Almost all courts find a way to apply a judicially-narrowed rule of criminal liability retroactively but refuse to do the same when the scope of liability has been broadened. The United States Supreme Court, after a period when it made some new constitutional rules of criminal procedure selectively prospective, has now settled on a "firm rule of retroactivity," 184 binding all courts. This retroactivity, however, reaches back only to cases in which direct appeals remain available. Collateral attack of a conviction based on a subsequently announced procedural rule is permitted in federal courts only within the narrow exceptions defined in Teague $v$. Lane and the AEDPA. ${ }^{185}$ State courts collaterally reviewing a judgment are not bound by Teague or the AEDPA and apply a variety of approaches. These divergent standards show that the retroactivity and prospectivity of judicially-created law remains profoundly controversial in American jurisprudence.

The disagreement has often been expressed in terms of the practice's relation to the doctrine of stare decisis. The declaration of a genuinely new rule is, by definition, a break with the discipline of stare decisis. Still, its advocates have argued that prospective overruling is supported by that doctrine's principal purposes. "By not applying a law-changing decision retroactively, a court respects the settled expectations that have built up around the old law."186 This argument, however, turns out to be two-edged sword. The very capacity of a prospective ruling to accommodate justified reliance may remove one of the greatest incentives to adhere to precedent:

By announcing new rules prospectively or by applying them selectively, a court may dodge the stare decisis bullet by avoiding the disruption of settled expectations that otherwise prevents us from disturbing our settled precedents. Because it forces us to consider the disruption that our new decisional rules cause, retroactivity combines with stare decisis to prevent us from altering the law each time the opportunity presents itself. ${ }^{187}$

184. Landgraf v. USI Film Prods., 511 U.S. 244, 278 n.32 (1994).

185. See supra text accompanying notes $156-80$.

186. James B. Beam Distilling Co. v. Georgia, 501 U.S. 529, $551-52$ (1991) (O'Connor, J., dissenting).

187. James B. Beam, 501 U.S. at 548 (opinion of Blackmun, J.). See also id. at 549 (Scalia, J., concurring). Prospective-only judgments are also obviously in tension with the stare decisis policy of equitable treatment of litigants insofar as it distinguishes parties solely on the basis of when their dispute arose. See Carl A. Auerbach, A Revival of Some Ancient Learning: A Critique of Eisenberg's The Nature of the Common Law, 75 Minn. L. Rev. 539, 571 (1991). 
"Prospective decisionmaking," according to Justice Scalia, "is the handmaid of judicial activism, and the born enemy of stare decisis." 188

Prospective overruling, therefore, may encourage and legitimate judicial legislation. ${ }^{189}$ This has been a criticism of non-retroactive judgments as long as they have been rendered in American courts. ${ }^{190}$ It was also a prominent theme in the Supreme Court's debate on the practice in the second half of the twentieth century. Justice Harlan accused those willing to apply a new rule of criminal procedure only prospectively of feeling "free to act, in effect, like a legislature, making its new constitutional rules wholly or partially retroactive or only prospective as it deems wise."191

This disapproval, of course, assumes that it is improper for courts to make law. It depends, that is, on some form of the declaratory theory of adjudication. Indeed, in a concurring opinion endorsing full retroactivity, Justice Scalia quoted extensively from Blackstone. ${ }^{192}$ But this was a theory which the advocates of limited retroactivity had already rejected, in fact, ridiculed for decades. ${ }^{193}$ Advocacy of non-retroactive judgments has, in fact, often been associated with the American legal realist critique of formalist jurisprudence. One commentator was pleased at the prospect that "the more courts begin to utilize prospective overruling the more it will become obvious that the judge is, in fact, inescapably a judicial legislator." 194 And, in an unusually candid judicial recognition of the realist position, Justice O'Connor defended non-retroactive judgments by citing Marbury v. Madison: "[P]recisely because this Court has 'the power to say what the law is,' when the Court changes its mind, the law changes with it."195 By the late twentieth century, this

188. Harper v. Va. Dep't of Taxation, 509 U.S. 86, 105 (1993) (Scalia, J., concurring).

189. See Rogers, supra note 36, at 36-37 (" $[\mathrm{A}] \mathrm{n}$ exploration of this doctrine of prospective overruling is but a specialized examination of the limits of judicial lawmaking with particular regard to the element of time of application of the overruling decision.").

190. See, e.g., Gelpcke v. City of Dubuque, 68 U.S. 175, 211 (1863) (Miller, J., dissenting) ("[The majority] . . holds that the decision of the court makes the law, and in fact, that the same statute or constitution means one thing in 1853, and another thing in 1859.").

191. Mackey v. United States, 401 U.S. 667, 677 (1971) (Harlan, J., concurring and dissenting).

192. Harper, 509 U.S. at 106-07 (Scalia, J., concurring). In criticizing Linkletter, Paul Mishkin stressed the "symbolic ideal reflected in the Blackstonian concept and ... the emotional loyalties it commands.") Mishkin, supra note 128, at 66 (emphasis added).

193. See, e.g., Traynor, supra note 20 , at 535 (deriding as "moonspinning" the idea that "judges do no more than discover the law that marvelously has always existed, awaiting only the judicial pen that would find the right words for all to heed.").

194. See Levy, supra note 12, at 16.

195. James B. Beam Distilling Co. v. Georgia, 501 U.S. 529, 550 (1991) (O’Connor, J., dissenting) (citations omitted) (quoting Marbury v. Madison, 5 U.S. (1 Cranch) 137 
was a position with which it was difficult to argue and it undermined the claim that non-retroactivity was somehow inconsistent with the nature of adjudication. ${ }^{196}$

To the extent that the practice of giving judgments only prospective effect reflects modern recognition of the law-making power of judges, we might expect it to be employed differently depending on the underlying source of the law being applied. The demise of the declaratory theory led first to the conclusion that the judicial creation and modification of common law rules were inevitably exercises of judicial legislation. The idea that enacted law does not pre-exist judicial cases invoking it, however, is markedly harder to sustain. It might follow that courts could limit the applicability in time of their common law judgments but not those bottomed on statutes or constitutions. ${ }^{197}$

A few cases support this intuition. The Massachusetts Supreme Judicial Court has held that " $[\mathrm{w}]$ here a decision does not announce new common-law rules or rights but rather construes a statute, no analysis of retroactive or prospective effect is required because at issue is the meaning of the statute since its enactment."198 For the most part, however, neither courts nor commentators have regarded the source of the law at issue as of much consequence to the temporal effect of a judgment. Cardozo thought there was no "adequate distinction" between changes of rulings concerning statutes or common law."199 Likewise, when he wrote the Supreme Court's Sunburst opinion, upholding the constitutionality of prospective overruling by state courts, he noted that the "alternative is the same whether the subject of the new decision is common law or statute." 200

In fact, some observers have noted that prospective rulings have been more common in the case of new statutory interpretations than

(1803). Justice Scalia later claimed that this interpretation of Marbury "would have struck John Marshall as an extraordinary assertion of raw power." Harper, 509 U.S. at 106-07 (Scalia, J. concurring).

196. See, e.g. Mackey v. United States, 401 U.S. 667, 677-81 (1971) (Harlan, J., concurring and dissenting).

197. See Roosevelt, supra note 78 , at $1076,1107$.

198. In re McIntire, 936 N.E.2d 424, 428 (Mass. 2010). Nevertheless, the Court limited the retroactivity of new interpretations of enacted law in two subsequent cases. See Shirley Wayside Ltd. P'ship v. Bd. of Appeals, 961 N.E.2d 1055, 1065 (Mass. 2012); Eaton v. Fed. Nat'l Mortg. Ass'n, 969 N.E.2d 1118, 1132-33 (Mass. 2012). See also Kendrick v. Dist. Attorney of Phila. City, 916 A.2d 529, 539 (Pa. 2007) ("[C] ourts should have the least flexibility where ... the holding at issue ... involves an interpretation of a statute."); State v. Cabagbag, 277 P. 3d 1027, 1041-42 (Haw. 2012)(the state Supreme Court's exercise of its supervisory power over lower courts may be made prospective).

199. CARDozo, supra note 12, at 148-49 (citation omitted).

200. Great N. Ry. Co. v. Sunburst Oil \& Refining Co., 287 U.S. 358, 365 (citations omitted). On Sunburst see supra text accompanying notes 14-18. 
in the case of new common law rules. ${ }^{201}$ The justification for such a priority has never been thoroughly explained. In Sunburst, Justice Cardozo assumed that the decision to apply judgments retroactively or prospectively - in whatever kind of case-was an aspect of the doctrine of stare decisis, that doctrine itself was a part of the common law, and, therefore, it was within the authority of the judges. ${ }^{202}$ One writer has suggested that individuals are more likely to rely on statutory or constitutional rights than common law rights and are therefore entitled to a greater degree of protection. ${ }^{203} \mathrm{~A}$ recent decision of the United States Sixth Circuit Court of Appeal addressed the "seemingly compelling" argument that a state court was without power to treat a statutory interpretation as anything but fully retroactive. The court noted that legislatures often write broad statutes, relying on courts to refine and apply them. "[T]he judicial development of the legislatively-created concept is little different from the development of judicially-announced law" so a court could properly consider whether its interpretation should applied retroactively. ${ }^{204}$

In sum, the current confused state of the law on the possibility of limited retroactivity of judgments demonstrates a persistent and possibly irresoluble tension in the American view of law and of the roles of legal institutions. The separation of powers, a fundamental dogma of the constitutional system, assumes that we are able to identify with some confidence what distinguishes "legislative" from "judicial" functions. ${ }^{205}$ The declaratory view of adjudication fit comfortably with that assumption. But that view, that the content of the law exists prior to and independent of its application by the courts, now seems irretrievably lost. Even with respect to written law, modern notions of interpretation have blurred the line between legislation and adjudication. ${ }^{206}$ In these circumstances, what can it mean to complain that a prospective-only ruling is inconsistent with the judicial role? The difficulty is illustrated in one of Justice Scalia's separate opinions in the Supreme Court's series of cases effecting the transition from limited retroactivity to a "firm rule of retroactivity": ${ }^{207}$

I am not so naive (nor do I think our forebears were) as to be unaware that judges in a real sense "make" law. But they

201. See Henry M. Hart \& Albert M. Sacks, The Legal Process: Basic Problems in the Making and Application of Law 604 (William N. Eskridge \& Philip P. Frickey, eds. 1994); Milan M. Durgala, Note, Prospectively Overruling the Common Law, 14 SYR. L. REv. 53, 54-56 (1962-63).

202. Sunburst, 287 U.S. at 366.

203. See Rogers, supra note 36, at 54.

204. See Volpe v. Trim, 708 F.3d 688, 702 (6th Cir. 2013)

205. See Currier, supra note 21 , at 221-22.

206. See Richard S. Kay, Judicial Policy-Making and the Peculiar Function of Law, 26 U. QUEENSLAND L.J. 237, 243-49 (2007).

207. Landgraf v. USI Film Prods., 511 U.S. 244, 278 n.32 (1994). 
make it as judges make it, which is to say as though they were "finding" it-discerning what the law is, rather than decreeing what it is today changed to, or what it will tomorrow be. ${ }^{208}$

In his separate opinion in the case, Justice White pounced on this obscure description of the proper role of courts:

$[\mathrm{E}]$ ven though the Justice is not naive enough (nor does he think the Framers were naive enough) to be unaware that judges in a real sense "make" law, he suggests that judges (in an unreal sense, I suppose) should never concede that they do and must claim that they do no more than discover it, hence suggesting that there are citizens who are naive enough to believe them. ${ }^{209}$

There is no more contested issue in American law than the propriety of independent policy-making by courts. ${ }^{210}$ Prospective judgments dramatically spotlight that controversy. It is not surprising that this has been a difficult and contentious issue for courts and commentators alike. It will be impossible to arrive at a coherent and generally accepted approach to the retroactive or prospective application of new judicial declarations of law until there is an equally well accepted definition of the proper allocation of lawmaking authority.

208. James B. Beam Distilling Co. v. Georgia, 501 U.S. 529, 549 (1991) (Scalia, J., concurring)

209. Id. at 546 (White, J., concurring).

210. See generally Kay, supra note 206. 
[Vol. 62 